\title{
The role of mobile phones in the mediation of border crossings: A study of Haiti and the Dominican Republic
}

\author{
Heather A. Horst ${ }^{1}$ and Erin B. Taylor ${ }^{2}$ \\ ${ }^{1}$ RMIT University; ${ }^{2}$ Universidade de Lisboa, Portugal
}

This article draws upon recent work among Haitian migrants living at the Haitian-Dominican border in order to examine the role of mobile phones in cross-border movement in the region. Like other migrants and displaced populations, Haitians use technologies such as mobile phones to keep in touch with their families and maintain social relations as well as organising economic activities and the circulation of remittances. Yet the dependence of Haitian workers on geographic mobility for work and livelihood also requires developing and maintaining relationships across borders. The focus upon understanding relationships formed within and beyond the southern border region of Haiti and the Dominican Republic seeks to make ethnographically visible the role of the mobile phone in mediating different forms of mobility.

Keywords: Mobile phones, mobility, material culture, borders, Haiti, Dominican Republic

\section{INTRODUCTION}

It is eleven o'clock on a Friday morning and the bi-national market, located on the Dominican side of the southern border with Haiti, is in full swing. Female Haitian traders, known as Madame Saras, ply a range of wares, including clothes and beauty products from Port-au-Prince, and vegetables and coffee beans from the nearby countryside. A few Haitian men sell mobile phones, televisions, and radios that they have imported by bus, boat, and motorbike from Jacmel in Haiti's south. At the back of the stalls, Dominican men park large trucks full of coconuts, plantains, and other agricultural products, some of which have been transported nearly five hundred kilometres from the Samaná Peninsula. The exhaustive travel is considered to be worth the lucrative sales they make in this small, yet buzzing, market located right on the edge of the Pedernales River separating the Dominican Republic from Haiti.

Mobile phones, barely known in the region less than a decade ago, play a crucial role in the economic and social activities of traders and service workers. Global research has demonstrated how traders and service workers use mobile phones to save time and money by checking and comparing prices (Donner 2004; Jensen 2007), engaging in micro-coordination (Ling 2004), and maintaining social networks critical for trade and livelihood (Horst and Miller 2005, 2006; Molony 2008, 2009). While in 
other contexts the blending of work activities and domestic activities enabled through the mobile phone may be viewed as problematic and exploitative (e.g., Wajcman et al. 2008; Gregg 2011), the highly mobile and variable livelihood practices of traders and service workers means that the mobile is a key tool for them to stay in touch with their friends and family, thus enabling emotional support as well as facilitating economic livelihood. Indeed, given the mobile phone's ability to transgress and compress space and time, there is increasing evidence that mobile phones themselves can be used to perform acts of mobility on behalf of their users, thereby freeing up time for economic and leisure activities or facilitating movement in ways that are not possible for people themselves given legal, social, and regulatory infrastructures.

Yet, in many ways, the relationship between new technologies and mobility is not particularly novel. Along with shipping, forms of land transport, the aeroplane, the telegraph, and money transfer services, the mobile phone is just one of the more recent tools that humans have adopted to overcome the restrictions of space and time (Maurer 2004; Sheller and Urry 2006; Sheller 2009; Horst and Miller 2012). To bring their produce to market in the Dominican Republic before accessible forms of transport became available, Haitian traders had to walk for up to five days to reach the border. Today they use a range of objects of mobility to navigate the border, including trucks, motorbikes, and bicycles. As we discuss in this article, other objects, such as money, mobile phones, identity cards, and clothing, also become routes through which mobility is facilitated. Yet how, when, and why particular objects of mobility become embedded in the practices of trading on the border of Haiti and the Dominican Republic is intricately tied to the particular characteristics of the border region.

Border regions are especially interesting places to understand the way objects of mobility operate. As zones that exist across and between more than one nation-state, they have a number of unique features. In the border of the Dominican Republic and Haiti, the existence of two completely different national systems of communication creates logistical challenges, primarily because the systems and infrastructures to support them, such as airtime, credit, SIM cards, regulatory regimes, and the mobile network itself, are disconnected (Larkin 2008; Goggin 2011; Bell and Dourish 2012; Horst 2013). Haitians who cross the border on a regular basis often require access to both the Haitian and Dominican telecommunications systems to enable their social and economic activities, a situation that creates difficulties for people struggling to keep two mobile phones or SIM cards active. However, using two systems augments Haitians' flexibility in how they make use of the border zone, including the navigation of state bureaucracy that governs their access to and coordination of movement. Finally, the documentation and surveillance of the border itself shapes mobility in particular ways. The mobile phone occupies a prominent place among these objects of mobility due to the way it facilitates the movement of people and other objects of mobility across the national border.

While transnational migration and everyday mobility have been a core focus of mobile communication literature, few studies have explored the ways in which mobility is shaped by the legal and technical infrastructures that constrain and 
permit everyday movement (for exceptions see Benítez 2006; Wallis 2013). Throughout this paper we examine how Haitians living on the southernmost border between Haiti and the Dominican Republic negotiate a bi-national telecommunication infrastructure in their everyday practices of movement. Bringing together perspectives on the ethnography of infrastructure (Star 1999; Bell and Dourish 2012), material culture studies (Appadurai 1988; Miller 1988, 2009; Myers 2001; Buchli 2002; Tilley et al. 2006; Barendregt 2012) and mobile communication research (Katz and Aakhus 2002; Donner 2004, 2008; Ito et al. 2005; Horst and Miller 2006; Pertierra 2006; Ling and Donner 2009; Goggin 2011; Ling and Campbell 2011), we explore the ways in which infrastructure is territorialised, yet also made mobile and de-territorialised in various ways by the people who use it. We begin with a discussion of the role that mobile phones play in everyday livelihood activities. We then turn to how objects of mobility, including mobile phones and transport systems, permit money to circulate independently of senders and receivers as part of the networks of relationships between people, markets, and objects. We argue that while one of the primary functions of national borders is to arrest mobility, border regions promote mobility because they provide opportunities for economic and social arbitrage. The use of objects of mobility, especially mobile phones, enables different kinds of infrastructures to materialise and be enlivened for particular purposes (Skuse 2005). These include social infrastructures between employers and employees, family members, and traders. Within the context of border regions, mobile phones effectively help people to overcome the border's restrictions and access the benefits that the border itself helps to create.

\section{MOBILE BORDERS}

As traders barter with potential buyers, Emmanuel realises that he has a problem. $\mathrm{He}$ is perched on his motorbike at the market's entrance, waiting to pick up a regular client, Laura, a Haitian woman who lives on the Dominican side of the border and visits the market to do her grocery shopping. Every market day (Mondays and Fridays), Emmanuel collects Laura at the appointed hour on his 100cc bike, and she pays him a fare of fifty pesos once they arrive at the market. But another customer has just turned up, a Madame Sara (market vendor) who cannot leave her stall and wants Emmanuel to pick up some sandals that a customer has requested. Emmanuel needs to call Laura, but he has no credit on his Haitian phone and he knows that Laura does not maintain a Dominican phone, despite the fact that she lives in the Dominican border town of Pedernales. Calling from his Dominican phone to her Haitian phone would be too expensive, as he would be charged at international rates. However, Emmanuel can easily drive across the footbridge leading into Haiti without showing any identification. In fact, from his current position in front of the market in Pedernales, he only has to ride approximately one hundred metres to the local Digicel vendor who sits by the side of the road in Anse-à-Pitres. At this moment in time, the official border barely exists for Emmanuel. 
Emmanuel has no special privileges that allow him to cross the border easily; indeed, at other border crossings (such as Jimaní), Emmanuel would be restricted from coming into the country because he does not have a Dominican work visa. However, the checkpoint between the towns of Pedernales on the Dominican side, and Anse-à-Pitres on the Haitian side, allows undocumented crossing (Martínez 1995, 1999). Dominican customs at Pedernales generally does not request passports unless one is travelling beyond the town, and even national identity cards normally stay in one's pocket. For anyone wishing to traverse the administrative line separating the two nations, crossing is merely a matter of walking over a concrete footbridge that spans the tree-lined Pedernales River and passing through a flimsy wire gate that remains open between eight in the morning and five in the afternoon. Indeed, during the dry season, it is possible to walk, ride, or drive over the border through the riverbed.

Given the relative porosity of the border region, Haitians will travel from as far away as Port-au-Prince to cross here. Anse-à-Pitres was a popular place to cross into the Dominican Republic after the earthquake of January 2010. Hundreds of Haitians entered the region to seek refuge with their relatives in Pedernales and other parts of the Dominican Republic. However, the vast majority of traffic comes from residents of Anse-à-Pitres who enter Pedernales daily to work, shop, or use services that are not available on the Haitian side of the border. These include accessing some health and education services, obtaining Internet access, paying bills, sending or receiving remittances, buying phone credit, and travelling further afield.

The porosity of the border makes life easier for Haitians, but it also symbolises a long-standing historical problem of cross-border relations and economic inequality (Augelli 1980; Derby and Turits 1993; Derby 1994; Martínez 1995, 1999; Turits 2002; Bartlett et al. 2011). Although economic and bureaucratic barriers to entry are low, the border incorporates power relations that impact upon unfettered mobility. Haitians crossing into the Dominican Republic on non-market days are expected to pay Dominican guards a fee of 50 pesos or gourdes, and repeatedly report harassment by them. That Haitians have a greater need to travel than Dominicans reflects their dependence upon the Dominican Republic due to their greater poverty, isolation from other town centres, and a range of other social and economic and social factors. For example, Madame Saras and other traders buy goods in Port-au-Prince or Jacmel to sell in the Dominican Republic; Haitian men pass through the border on their way to employment in Santo Domingo and further afield, and children move from Haiti to the homes of relatives in the Dominican Republic to improve their access to schooling. Haitians living in the Dominican Republic also travel back to Haiti to visit family.

The transport route through the southern border is bureaucratically simpler than travelling through the main border at Jimaní, but it is more complex in terms of transport. Travellers catch a bus to Pedernales, walk or hire a motorconcho (motorbike taxi) to take them as far as the border, then walk across the bridge into Anse-à-Pitres. On market days they wait on the beach for an open fishing boat with an outboard motor to transport them overnight to Marigot, located approximately sixty kilometres 
to the west. Motorcycles also travel as far as Belle-Anse, located forty kilometres west of Anse-à-Pitres, but at 800-1000 gourdes (AU\$18-23) they are far more expensive than the 250 (AU\$6) gourde boat trip. Heading north from the border, a newly paved road leads as far as Thiotte, but bad roads and missing bridges make the remainder of the journey to Port-au-Prince an onerous one for the trucks that traverse the route daily, laden dangerously with goods and passengers.

\section{MOBILE COMMUNICATION INFRASTRUCTURES ON THE BORDER}

As the literature on transnational communication highlights (e.g., Paragas 2005; Horst 2006; Panagakos and Horst 2006; Wilding 2006; Madianou and Miller 2011), communication technologies such as the mobile phone are crucial to maintaining social networks and relationships; facilitating the flow of goods, people, and money, and managing households and money across national borders. In many places around the world, new telecommunications regulations, coupled with liberalisation measures that took place at the turn of the century, have significantly transformed the experience of connectivity and communication (Castells et al. 2006; Ling and Donner 2009; Goggin 2011). This is the case across Hispaniola where mobile phone penetration has recently approached one hundred per cent in both Haiti and the Dominican Republic. Since 2006, mobile subscriptions in Haiti have increased to over 2.4 million, and have spread from five per cent to thirty per cent of the population (estimates suggest around ninety per cent penetration in the capital of Port au Prince). In the Dominican Republic there are now over seven times more mobile phones $(7,801,858)$ than landlines, with mobile penetration rates estimated at 80.1 per cent.

There are also now four major mobile phone carriers in the border region. Digicel and Natcom operate in Anse-à-Pitres (Haiti) and Claro (formerly Codetel) and Orange operate in Pedernales (Dominican Republic). Digicel Haiti was the first telecommunications company to establish service in Haiti in May 2006. Voilá GSM was launched in Haiti on 21 October 2005, but Digicel aquired Voilà GSM in 2012. The newest player in the Haitian telecommunications market is Natcom, ${ }^{1}$ who established virtually nationwide service in just a couple of years. Their closest tower to Anse-à-Pitres is roughly forty kilometres away and service is therefore not entirely reliable. Before Digicel arrived, residents of Anse-à-Pitres depended upon Dominican-based services (Codetel/Claro and Orange). They were able to use these services at home in Anse-à-Pitres because the signals are accessible on the Haitian side of the border. According to anecdotal reports, they can be picked up some forty kilometres from the border. While these services allowed people to call family, friends, and others living throughout the Dominican Republic, it meant that they if they wanted to call within Haiti they would be charged the cost of an international call. Now, however, many residents avoid the high prices associated with international calls by using Haitian mobile services, with many residents maintaining multiple mobile phones or SIM cards for telecommunications providers on both sides of the border. These form the 
most important part of a range of items that directly or indirectly facilitate border crossing. It is to these objects of mobility that we now turn.

\section{OBJECTS OF MOBILITY}

Throughout this project, we examined the materiality of the border in terms of the objects that people carry or use, how these individual objects relate to other objects in a set, and the repertoires of practices and meanings that emerged from their collective use in economic and social arbitrage across the border. Contextualised within a broader study of life in the region, our aim was to understand the mundane ways in which people strategised mobility in light of the different currencies, citizenship status, languages, telecommunications infrastructures, economic opportunities, and power relations that distinctly shape the ways in which mobility and movement are possible (Hjorth 2008; Wallis 2013). To gain a deeper understanding of mobility on the border, our team conducted interviews with forty individuals living in the border region. We also carried out a survey with two hundred respondents, primarily with people who worked in and around the market that spans the border.

With a subset of ten individuals, we undertook a modified version of Ito et al. (2009) 'Portable Kit Study', which examined the use of objects by young urban professionals living in Los Angeles, Tokyo, and London. For our research, we focused on the items that border residents carry with them as they live, work, and socialise in and around the border region. ${ }^{2}$ Studies carried out by other researchers in more industrialised nations show that portable kits often include the latest gadgets such as music players, laptops and mobile phones, as well as more mundane objects such as credit cards, transit cards, keys, and ID cards. Our interviewees shared some objects in common with interviewees in other studies, especially ID cards, mobile phones, keys, and forms of currency. However, portable kits on the border of Haiti and the Dominican Republic lack most of these technological items. Instead, the highly politicised context of the border and the differing infrastructures mean that having 'papers', forms of identification, a mobile phone that would work in the destination, and enough money to facilitate this movement, took on a heightened significance. Given that regulation of movement in the border region depended on the practical and symbolic properties of multiple objects, we also extended our study to include pockets, shoes, hats, jewellery, clothing, bibles, hand cloths, and in one case, a motorbike.

We recruited portable kit study participants primarily from our initial interview and survey pool. In most cases, background interviews focused upon their mobile phone use and their impressions of the border region. Where time had passed or an initial interview was not conducted, we started the portable kit interview with a set of background questions. We then requested that participants take the objects they carry with them on a 'normal' day out of their bags, pockets, and wallets, and display them on a flat surface. After an initial discussion of the objects, we worked with each participant to distinguish between the items that they carried with them on an everyday basis and those they carried less frequently. We then asked participants to sort the 
objects in order of their importance. We discussed each object with the interviewee, leaving the mobile phone until last because it took up the most interview time. Interviews ranged from forty-five minutes (in the case of one participant who had been interviewed multiple times and did not carry many items), to three hours for people with many items or an unusually extensive collection of phones and SIM cards.

\section{MOBILE MEDIATIONS: RELATIONSHIPS, LIVELIHOODS, AND MONEY}

Haitians living on the border exhibit a range of relationships and livelihood practices that reflect their mobility. Haitian women traditionally run the country's informal market system and therefore travel extensively (Mintz 1962). Men may migrate to find work and stay away for long periods of time, but they rarely accompany women as they travel to buy or sell goods (Schwartz 2009). Haitian family members who share a primary residence may therefore spend a great deal of time apart from each other, and those who travel often stay with members of their extended family in other towns. Mobile phones are used extensively between families across multiple households to plan the practicalities and micro-coordination of visiting, such as making sure someone is home to let in the visitor. In addition, mobiles are used to reassure family members who are apart, such as through calling to let family members know that one has arrived safely at one's destination. For example, Patricia travels from her home in Anse-à-Pitres to Port-au-Prince every two weeks to buy goods to sell in the border market, where she has a stall that is well stocked with clothes, bags, and shoes. Her husband, who rents a field across the border in Pedernales, stays home to tend the vegetables and mind their house. Patricia calls her family in Port-au-Prince in advance to let them know when she plans to arrive. She also uses her mobile to coordinate travel arrangements with fellow Madame Saras, as women often travel in pairs or small groups to keep each other company and lower costs. Their mobile phones are especially useful to coordinate their return from Port-au-Prince, where they all stay in different houses.

Despite the fact that the majority of our interviewees reported crossing the border for economic reasons, family still emerged as the greatest motivation for maintaining objects of mobility. Making a living is not so much an end in itself; instead, the purpose of economic activities requiring mobility is to maintain households. Among the Haitian migrants who participated in our study, the desire to stay connected to family who are dispersed throughout Haiti and the Dominican Republic is often realised through the mobile phone. In our interviews and portable kit study, we asked people to list the last three people they had called (and vice versa). With both women and men we interviewed, two out of the last three calls were to family members such as mothers, sisters, or partners. The third person was usually a close friend. In fact, the primary reason people gave for owning a mobile phone was the ability to be contacted and/or contact someone in the family.

Staying in touch via the mobile phone often takes a great deal of planning and commitment. The need to keep the phone battery charged, store funds on two phones 
in the event of an emergency, or even make a phone call, involves coordination and planning (Skuse 2005). Few houses in Anse-à-Pitres have electricity, whereas most households have electricity in Pedernales. Residents of Anse-à-Pitres who are employed in Pedernales charge their phones at work during working hours, or pay a small fee to charge their phone in a business in Anse-à-Pitres that is connected to electricity (such as the microcredit institution Fonkoze). Some people have small solar panels that they use to keep their phones charged. Alongside keeping a charge, a significant issue with maintaining a phone is keeping phone credit topped up. People generally need to cross the border to buy credit for their Dominican phones, however, the border is only open from $7 \mathrm{AM}$ to $6 \mathrm{PM}$. On non-market days, it costs money to cross, thereby driving up costs of accessing credit. ${ }^{3}$ People overcome these limitations in various ways, including sending each other airtime or paying someone like Emmanuel to top up their credit for them. The cost of maintaining a mobile phone to facilitate staying connected is also an issue. Alain, a young man living in Pedernales, noted that once you have a mobile phone:

You are obliged to call people, and if you have to call Haiti and you have trouble talking, then you spend a lot of money. You look at your clock and it's already dinnertime, you're going to end up not having any dinner ... The positive thing about cell phones is to be able to greet your people, to know about your most important friends. For example, you are my friend, I need to talk to you, let me call my friend to see that how you are. 'Hi Fulano, where are you? I'm in Pedernales, sitting here and drinking a juice. I'm resting, I'm dining, I'm bathing, I'll call you later, I send you greeting.' I call my mother, my old woman, and I ask her how her day is going. Because these people are so far away that you can't see with your own eyes whether they are okay or not. (Alain, Pedernales, May 2012)

Alain complained to us that the problem with owning a phone is that people will strategise to force you to pay for calls, such as by calling briefly and hanging up. This differs from 'flashing' and 'beeping' found in other parts of the developing world (see Donner 2008), in that the 'hang up' among Haitians living in the border is not in and of itself viewed as a form of communication. Voice calls still dominate the ideas of what a 'real' communicative act involves and we witnessed little to no creation of communicative languages and codes through SMS and voice calls. In fact, when we interviewed Alain a second time, he had temporarily given up possession of a phone because he felt that he did not have sufficient funds to maintain it. By giving his phone to his girlfriend, he limited his expenditure to the partial maintenance of her call costs, rather than having to pay to call his family and friends. However, he viewed mobile phone ownership as absolutely essential for work and socialising, and planned to acquire another one as soon as he felt more economically stable. Alain's quest to purchase and maintain a phone was complicated by the fact that he was trying to save money to buy a new Dominican visa so that he could work in Santo Domingo. Alain had already spent around eight years living in different parts of the Dominican Republic, and had dozens of friends who expected him to stay in touch, which greatly inflated his calling costs. 
Miguelina, a middle-aged woman living in Pedernales, did not face the same issue of costs due to intensive social relationships maintained via the mobile phone because she had never travelled and knew few people outside the border region. She had just three people's names stored in her Digicel phone: her mother, a male in-law (cuñado), and a female friend (amiga). Miguelina is perhaps an extreme example of the preoccupation with staying connected almost exclusively to family members. She notes that she spends about twenty pesos per week (or around AU\$.50) calling her mother in Haiti to see how she is doing. On the first of each month she will also add fifty pesos (or AU\$1.25) to her account because Digicel will double any credit she buys. Miguelina plans for this money to last her the whole month. Although Miguelina is aware of a Digicel offer that provides free calls between midnight and 6AM she has never taken advantage of it and notes she is too sleepy during these hours. Other interviewees were well aware of these promotions and sought to take advantage of them.

For some people, keeping in touch with non-related household members is at least as important as keeping in touch with family. While households are traditionally composed of blood relatives, they may also be composed of people with no biological relationship to one another. This is especially the case when people adjust their living arrangements to suit their economic need. In Haiti there has been a long tradition of creating flexible household structures that span social and economic needs in rural and (more recently) urban Haiti. These are referred to as lakou. They emerged during plantation slavery and enabled biological and fictive kin to pool together economic, material, and social resources. The lakou is also intertwined with religious practice, especially vodou (for more details about lakou and families in Haitian society, see Edmond et al. 2007; LaRose 1975; Richman 2009; Stevens 1998).

Claudine, a woman in her late fifties, has multiple livelihood strategies. She rents a house in Anse-à-Pitres but is away for two weeks of every month. She travels by boat directly from Anse-à-Pitres to a Dominican island where she purchases small fish from Haitian fishermen. Over the course of two weeks, she dries them in the sun and then brings them back to Anse-à-Pitres to sell to buyers in a small market on the local beach. These buyers then transport the dried fish by open boat deeper into Haiti, where they resell them in Marigot, Jacmel, and Port-au-Prince. Claudine's children are young adults, and they care for each other with the help of a young Haitian woman, Monica, who sublets a room in their house. Monica moved to Anse-à-Pitres from a small town near Santo Domingo, where she was living with her mother and her young son. Monica left her own family in the hope of carving out a career for herself as a trader on the border. She has essentially joined Claudine's household, as she has accepted responsibilities that go beyond the purview of a visitor or tenant. Monica therefore has two households to maintain where her key role is to provide social support, given that she plans to support her son economically when she earns more money. She uses her mobile phones extensively to coordinate her trading activities and stay in touch with her mother and son. Claudine, however, does not have mobile reception while she is drying fish on the island, and so any urgent business must be resolved between Claudine's two children and Monica. In some cases, business 
decisions must wait until Claudine returns. Monica can constantly be seen carrying her Dominican mobile phone on a lanyard, worn around her neck. It is more useful than her Haitian phone because her main customers, as well as her mother and son, live in the Dominican Republic. She therefore also prioritises its maintenance: there is no electricity in her house, so she charges her phone for free in the boutique of a friend who lives on Anse-à-Pitres's main street. Monica generally leaves her Haitian phone at home, because she rarely needs to call anyone in Haiti who is not within twenty minutes' walking distance. Like the emergence of the lakou in previous generations, the mobile phone enables social support and forms of exchange and cooperation, as well as care and a sense of belonging.

\section{MOBILE PROXIES}

One of the reasons why objects of mobility are so important in the border region is because they can compensate for the pervasive immobility experienced by residents of the region (Hjorth 2008; Wallis 2013). As we have seen, while many people are highly mobile, there are certain factors that severely limit mobility, including restrictions on crossing the border, difficulties obtaining visas, and high transport costs. Money is another important object of mobility whose circulation is imperative, but, as an object, it faces a number of obstacles due to infrastructure, regulation, and availability. For example, our initial research on monetary ecologies and repertoires suggested that less than one per cent of residents of Anse-à-Pitres had a bank account (Baptiste et al. 2010). Fonkoze, one of the largest microfinance organisations in Haiti, opened in 2011 and now provides two ways of sending money: by MoneyGram and through Digicel's TchoTcho Mobil (mobile money service). Western Union also opened in Anse-à-Pitres in 2010. While there had been a Western Union office in Pedernales for years, some Haitians reported to us that they did not use it because they felt the staff discriminated against them.

Emmanuel is one of a growing pool of residents who are taking advantage of new ways to send money. He has clients who will send him money and shopping lists from as far away as Jacmel. They are often people he knows, such as friends or relatives, because part of his family is from that region. Since mobile money arrived in Anse-à-Pitres in February 2012, Emmanuel has been receiving money via Digicel's TchoTcho Mobile. If he wants to send money, Emmanuel visits Fonkoze to put money on his TchoTcho Mobile account. He then uses his phone to send money to another Digicel phone number. When someone sends him money, Emmanuel receives a text message stating the amount that has been transmitted. He can then visit Fonkoze to take out the cash. One particular friend sends him money once per month to pay his Sky satellite television bill, for which he uses a Dominican company even though he lives eighty-five kilometres away in Jacmel. Emmanuel receives a text message from TchoTcho Mobile saying that the money has arrived, and then goes to Fonkoze, a Haitian microcredit bank with a branch in Anse-à-Pitres, to withdraw the cash from his account. He then crosses into 
Pedernales, where he pays his friend's bill at the bank. Emmanuel reported that he would be paid between one hundred and two hundred pesos (US\$2.35 to US\$4.70) to pay a Sky bill of two thousand pesos (US\$47).

Despite the increasing presence and accessibility of these new services, many residents continue to depend upon alternative, informal transfer services. For example, Joseph, a fisherman in Anse-à-Pitres, uses the boat transfer service once per month on average. He has children studying and living with relatives in Jacmel and he also has family in Santo Domingo who sometimes send him money. Joseph has two mobile phones (one Haitian with Digicel and one Dominican with Claro) so that he can maintain contact with both sets of relatives. He cannot visit his relatives in Santo Domingo because he does not have a passport or the four thousand peso bribe to pay the military to let him pass without identification. When he can, he sends money to his children in Jacmel. As he described it:

There are times when I send four hundred pesos, or two hundred or five hundred as well. Whatever I find, I send, because the life of us Haitians is difficult. We barely have a President. We work hard and the government isn't even building a school or anything. But this isn't the case in the Dominican Republic or Spain. Haitians work more than anyone else in the world. We have to work hard and this makes people old because this effort is too much for the little money that we earn. (Joseph, Anse-à-Pitres, July 2010)

To send money via boat, Joseph speaks with a captain and gives him the cash with the name and phone number of the intended recipient. If the sender does not have a phone, a neighbour or friend's number will be given. Once the money has been handed over, Joseph will send a text message to the receiver with the amount of the transfer and the captain's name and phone number. The receiver must then meet the captain in Marigot on the morning the boat arrives. Marigot is a small town and the boats do not travel again for another three or four days, so the captain is generally not difficult to locate. If there are any doubts, mobile phones are used to keep in contact. In the past year, however, two boats have capsized, their occupants and money washed away in the sea.

The examples of Emmanuel and Joseph demonstrate the creative ways in which people combine objects of mobility to overcome restrictions on movement and achieve their goals. It is worth keeping in mind, however, that not everyone has access to sufficient objects of mobility to take advantage of low-tech solutions such as a fleet of fishing boats, let alone high-tech options such as mobile money. Nicolas, for example, earns just enough money to feed himself and his family. He has no excess cash that he can send on to relatives; nor does he receive any money. Nicolas has a wife and two school-aged children, and he earns AU\$30 per week carting goods, baggage, and people onto the waiting boats, and working as a crew member traveling backwards and forwards to Marigot. He is three months behind on rent payments for his house, and when we spoke with him in 2010 he could not travel to find better-paid work because he was sick. Before the earthquake he received assistance occasionally from his relatives in Port-au-Prince, but he has not been able to 
contact them since then because he has no phone or even spare money to buy a calling card to use on someone else's phone. He is very stressed because he does not even know if his relatives survived:

The earthquake killed a lot of people in Port-au-Prince, and I don't know if my relatives are alive or dead. I had my uncle's telephone number but I lost it. I want to go past the house of a neighbour here who knows well how to use the telephone, but I have no money to give him. (Nicolas, Anse-à-Pitres, July 2010)

Nicolas is an important case because he has employment opportunities and family in other towns in Haiti, but he lacks the financial and technological resources to take advantage of opportunities. As a result, he is also unable to cultivate and/or expand his social capital through communication (e.g., 'link up', Horst and Miller 2005), a strategy that many Haitians and others in the Caribbean develop as a safety net (Horst and Miller 2006). Nicolas's situation, always precarious, has worsened emotionally and financially since the earthquake. His case is a grave reminder of the limitations of employment to provide security in a country where wages are so low that they barely permit subsistence survival. Mobile phones and the social networks they enable and often extend are pivotal to the ability of very poor Haitians to manage the problems they face in their everyday lives, including in times of crisis, but are of little help to those who cannot afford them.

\section{CONCLUSION}

Border regions are constituted by the ability of people who move through them to engage in a kind of cross-border arbitrage, in which they make a living by taking advantage of different markets for labour and goods. In the process of engaging in livelihood strategies across national borders, social relationships become constituted in and across these differential spaces. The tension between the border as a symbol of restriction and separation, and the lived experience of transgression by residents, means that objects of mobility become particularly pivotal in strategies to stay mobile. Hence, while objects of mobility facilitate relationships just as they would anywhere else, in the border zone they take on particular properties and capabilities. As we have seen, keeping mobile phones operational is a priority for people whose livelihood depends upon mobility across borders. Those who seek to be mobile but cannot maintain a mobile phone feel its absence keenly. The mobile phone's capacity for communication and coordination means that it enables further practices of mobility, including coordinating the movement of goods and people. Mobile phones replace other objects of mobility, as evidenced in the shift from sending remittances by boat to the use of mobile money services, but they also become integrated within a set of pre-existing practices around trade and the leveraging of flexible social networks for the creation of households and everyday livelihood. Finally, the phone can also act as a proxy for people through negating the need for physical mobility, such as the need to travel in person to visit relatives or pay a bill. 
Through strategically employing two entirely different national telecommunications systems in tandem, residents of the Dominican-Haitian border region circumvent many of the border's restrictions on mobility. This essentially enables residents to collapse the region into a single, integrated zone where lives and livelihoods are created and recreated. Yet it is important to remember that the practices of agency, hacking, and arbitrage we see in and through the mobile phone are always partial, fragile, and temporal (Tsing 2005; Horst 2013; Sheller 2013). As we saw with the closure of the border during the cholera outbreak in late 2010, borders can be closed, politics can lead to greater surveillance, and new policies and crises can create circumstances wherein the formal and informal rules of engagement can change quite rapidly. The mobile phone's role as an object of mobility can be viewed as the most recent materialisation of social and economic configurations in the border, one that may shift and change over time as other objects of mobility come to the fore.

\section{ACKNOWLEDGEMENTS}

This paper draws from research funded by the Institute for Money, Technology and Financial Inclusion at the University of California, Irvine, USA. We thank participants at the IMTFI Annual Conference (December 2012) and participants at the Mobile Africa Revisited conference at the University of Leiden, Netherlands in February 2013 for feedback on earlier versions of this paper.

Please send correspondence to Heather A. Horst and Erin B. Taylor: heather.horst@rmit. edu.au; erin@erinbtaylor.com

\section{NOTES}

1 Natcom is owned by a share of the Haitian national telecommunication company (TELECO) and Viettel Group, the state-owned company of Vietnam. Natcom offers cable infrastructure in Haiti for fixed, internet, and mobile services.

2 All interviews were audio recorded and video recorded. In keeping with our ethics requirements, participants given the option of revealing their face; three of the participants (all women) requested their faces be hidden. Interviews were conducted in Spanish and Haitian Creole with the assistance of a (Dominican) research assistant and a translator (where requested or necessary); most participants were fluent in Spanish.

3 During the first phase of our fieldwork in 2010, Pedernales and Anse-à-Pitres were in different time zones but this changed while we were in the field in 2012 .

\section{REFERENCES}

Appadurai, A. (ed.) 1988 The Social Life of Things (Cambridge Studies in Social and Cultural Anthropology). Cambridge: Cambridge University Press.

Augelli, J. P. 1980 Nationalization of the Dominican borderlands, Geographical Review 70: 19-35.

Baptiste, E., H. Horst, E. Taylor. 2010 Haitian Monetary Ecologies and Reportoires: A Qualitative Snapshot of Money Transfer and Savings. Report Submitted to the Institute for Money, Technology and 
Financial Inclusion November 2010. http://issuu.com/bill_maurer/docs/baptiste_horst_taylor_112310? viewMode=magazine, Accessed November 15, 2013.

Barendregt, B. 2012 Diverse digital worlds, in (eds) H. Horst and D. Miller Digital Anthropology. New York: Berg, pp 203-24.

Bartlett, L., K. Jayaram and G. Bonhomme 2011 State literacies and inequality: Managing Haitian immigrants in the Dominican Republic, International Journal of Educational Development 31: 58795.

Bell, G. and P. Dourish 2012 Divining a Digital Future. Cambridge: MIT Press.

Benítez, J. L. 2006 Transnational dimensions of the digital divide among Salvadoran immigrants in the Washington, D.C. metropolitan area, Global Networks 6(2): 181-99.

Buchli, V. (ed.) 2002 The Material Culture Reader. Oxford: Berg.

Castells, M., M. Fernandez-Ardevol, J. Qiu and A. Sey 2006 Mobile Communication and Society. Cambridge: MIT Press.

Derby, L. 1994 Haitians, magic and money: Raza and society in the Haitian-Dominican borderlands, 19001937, Comparative Studies in Society and History 36(3): 488-526.

Derby, L. and R. Turits 1993 Historias de terror y los terrores de la historia: La masacre Haitiana de 1937 en la República Dominicana, Estudios Sociales XXVI(92): 65-76.

Donner, J. 2004 Microentrepreneurs and mobiles: An exploration of the uses of mobile phones by small business owners in Rwanda, Information Technologies and International Development 2(1): 1-21.

Donner, J. 2008 Research approaches to mobile use in the developing world: A review of the literature, The Information Society 24(3): 140-59.

Edmond, Y. M., S. M. Randolph and G. L. Richard 2007 The Lakou system: A cultural, ecological analysis of mothering in rural Haiti, The Journal of Pan African Studies 2(1): 19-32.

Goggin, G. 2011 Global Mobile Media. London: Routledge.

Gregg, M. 2011 Work's Intimacy. Cambridge: Polity Press.

Hjorth, L. 2008 Waiting for immediacy: The convergent inertia of mobility and immobility, in (ed) K. Nyíri Towards a Philosophy of Telecommunications. Vienna: Passagen Verlag, pp 189-96.

Horst, H. 2006 The blessings and burdens of communication: Cell phones in Jamaican transnational social fields, Global Networks 6(2): 143-59.

Horst, H. 2013 The infrastructures of mobile media: Towards a future research agenda, Mobile Media and Communication January 1: 147-52.

Horst, H. and D. Miller 2005 From kinship to link-up: Cell phones and social networking in Jamaica, Current Anthropology 46(5): 755-78.

Horst, H. and D. Miller 2006 The Cell Phone: An Anthropology of Communication. Oxford: Berg.

Horst, H. and D. Miller (eds.) 2012 Digital Anthropology. New York: Berg.

Ito, M., D. Okabe and M. Matsuda 2005 Personal, Portable, Pedestrian: The Mobile Phone in Japanese Life. Cambridge: MIT Press.

Ito, M., D. Okabe and K. Anderson 2009 Portable objects in three global cities: The personalization of urban places, in (eds) R. Ling and S. Campbell The Mobile Communication Research Annual Volume 1: The Reconstruction of Space and Time through Mobile Communication Practices. New Brunswick, NJ: Transaction Books, pp 67-88.

Jensen, R. 2007 The digital provide: Information (technology), market performance, and welfare in the South Indian fisheries sector, Quarterly Journal of Economics 122(3): 879-924.

Katz, J. E. and M. Aakhus (eds.) 2002 Perpetual Contact: Mobile Communication, Private Talk, Public Performance. Cambridge: Cambridge University Press.

Larkin, B. 2008 Signal and Noise: Media, Infrastructure, and Urban Culture in Nigeria (a John Hope Franklin Center Book). Durham: Duke University Press.

LaRose, S. 1975 The Haitian Lacou, land, family and ritual, in (eds) A. Marks and R. Romer Family and Kinship in Middle America and the Caribbean. Institute of Higher Studies in Curacao: Willemstadt/Curacao, pp 482-501.

Ling, R. 2004 The Mobile Connection: The Cell Phone's Impact on Society. Burlington, MA: Morgan Kaufmann.

Ling, R., S. Campbell. 2011 (eds) The Mobile Communication Research Series: Volume II, Mobile Communication: Bringing Us Together or Tearing Us Apart? Edison: Transaction Books.

Ling, R. and J. Donner 2009 Mobile Phones and Mobile Communication. Cambridge: Polity. 
Madianou, M. and D. Miller 2011 New Media and Migration: Transnational Families and Polymedia. Cambridge: Polity Press.

Martínez, S. 1995 Peripheral Migrants: Haitians and Dominican Republic Sugar Plantations. Knoxville: University of Tennessee Press.

Martínez, S. 1999 From hidden hand to heavy hand: Sugar, the State, and migrant labor in Haiti and the Dominican Republic, Latin American Research Review 34: 57-84.

Maurer, B. 2004 Cyberspatial properties: Taxing questions and proprietary regimes, in (eds) K. Verdery and C. Humphrey Property in Question: Value Transformation in the Global Economy. Berg: Oxford and New York, pp 297-318.

Miller, D. 1988 Material Culture and Mass Consumption. London: Wiley-Blackwell.

Miller, D. 2009 Stuff. Cambridge: Polity.

Mintz, S. W. 1962 Living fences in the Fond-des-Nègres region, Haiti, Economic Botany 16(2): 101-05.

Molony, T. 2008 Running out of credit: The limitations of mobile telephony in a Tanzanian agricultural marketing system, Journal of Modern African Studies 46(4): 637-58.

Molony, T. 2009 Trading places in Tanzania: Mobility and marginalisation in a time of travel-saving technologies, in (eds) M. de Bruijn, F. Nyamnjoh and I. Brinkman Mobile Phones: The New Talking Drums of Everyday Africa. Langaa/Afrika Studiecentrum: YaoundÉ/Leiden, pp 92-109.

Myers, F. 2001 (ed.) The Empire of Things: Regimes of Value and Material Culture. Santa Fe: SAR Press.

Panagakos, A. N. and H. A. Horst 2006 Return to Cyberia: Technology and the Social Worlds of Transnational Migrants, Global Networks: A Journal of Transnational Affairs 6(2): 109-124.

Paragas, F. 2005 Migrant Mobiles: Cellular Telephony, Transnational Spaces, and the Filipino Diaspora, in (ed) K. Nyiri A Sense of Place: The Global and the Local in Mobile Communication. Vienna: Passagen Verlag.

Pertierra, R. 2006 Transforming Technologies: Altered Selves. Manila: De La Salle University Press.

Richman, K. 2009 Migration and Voodou (New World Diasporas). Gainsville: University of Florida Press.

Schwartz, T. 2009 Fewer Men, More Babies: Sex, Family, and Fertility in Haiti. Lexington, MA: Lexington Books.

Sheller, M. 2009 The new Caribbean complexity: Mobility systems, tourism and the re-scaling of development, The Singapore Journal of Tropical Geography 30: 189-203.

Sheller, M. 2013 The islanding effect: Post-disaster mobility systems and humanitarian logistics in Haiti, Cultural Geographies 20(2): 185-204.

Sheller, M. and J. Urry 2006 The New Mobilities Paradigm, Special Issue on Mobilities and Materialities, Environment and Planning A 38(2): 207-26.

Skuse, A. 2005 Enlivened objects: The social life, death and rebirth of radio as commodity in Afghanistan, Journal of Material Culture 10: 123-37.

Star, S. 1999 The ethnography of infrastructure, American Behavioral Scientist 43(3): 377-91.

Stevens, A. M. 1998 Haitian women's food networks in Haiti and Old Town, United States of America. PhD Dissertation, Brown University.

Tilley, C., W. Keane, S. Kuchler, M. Rowlands and P. Spyer (eds.) 2006 Handbook of Material Culture. London: Sage.

Tsing, A. L. 2005 Friction: An Ethnography of Global Connection. Princeton, N.J.: Princeton University Press.

Turits, R. L. 2002 A World Destroyed, A Nation Imposed: The 1937 Haitian Massacre in the Dominican Republic, Hispanic American Historical Review 82(3): 589-635.

Wajcman, J., J. Brown, M. Bittman 2008 Intimate connections: The impact of the mobile phone on work life boundaries, in (eds) G. Goggin, L. Hjorth Mobile Technologies: From Telecommunications to Media. London: Routledge, pp. 9-22.

Wallis, C. 2013 Technomobility in China: Young Migrant Women and Mobile Phones. New York: NYU Press.

Wilding, R. 2006 "Virtual" intimacies? Families communicating across transnational contexts, Global Networks: A Journal of Transnational Affairs 6(2): 125-142. 


\section{SUPPORTING INFORMATION}

Additional supporting information may be found in the online version of this article at http://wileyonlinelibrary.com/journal/taja:

Figure S1. The Dominican border opens at 7am. Photo by Gawain Lynch.

Figure S2. Mobile phones were an important item in our interviewee's portable kits. Photo by Erin Taylor.

Figure S3. Guards supervise border crossings on a busy market day. Photo by Gawain Lynch.

Figure S4. Solar panels and batteries are used to charge mobile phones. Photo by Gawain Lynch.

Figure S5. Madame Sara waits to enter the Dominican Republic to set up their market stalls. Photo by Yoselyn Espinal.

Figure S6. The footbridge spanning the Pedernales river dividing Haiti and the Dominican Republic. Photo by Gawain Lynch.

Figure S7. The bi-national market in Pedernales. Photo by Gawain Lynch.

Figure S8. One of our interviewees owned three mobile phones. Photo by Heather Horst. 